Volume 6 Issue 2, September 2021:pp. 187 - 198 Copyright @ LamLaj. Faculty of Law, Lambung Mangkurat University, Banjarmasin, South Kalimantan, Indonesia. ISSN: 2502-3136 | e-ISSN: 2502-3128. Open Access at: http://lamlaj.ulm.ac.id/web/

\title{
THE CONSEQUENCE OF THE LEGAL APPLICATION OF FOREST AREA DEFENSE PRINCIPLES AND APPROVAL PRINCIPLES
}

\author{
Berliane Rezty Anggriheny ${ }^{1}$, Regina Yusticia Nababan ${ }^{2}$ \\ ${ }^{1}$ Master of Notarial, Faculty of Law, Universitas of Airlangga \\ Jl. Dharmawangsa Dalam Selatan Surabaya, 60286, Indonesia \\ berliananggri@gmail.com \\ ${ }^{2}$ Master of Notarial, Faculty of Law, Universitas of Airlangga \\ Jl. Dharmawangsa Dalam Selatan Surabaya, 60286, Indonesia \\ rhereystcia@gmail.com
}

Submitted : 18/05/2021 Reviewed: 10/08/2021 Accepted:11/09/2021

\begin{abstract}
Law Number 11 of 2020 concerning Job Creation is believed to be able to save Indonesia because it is considered to be able to create jobs, assist small business actors, streamline regulations in terms of numbers and simplify regulations to make them more targeted. On the other hand, the job creation law is considered to be detrimental to many groups, such as workers such as laborers, fishermen, and farmers who are also considered to only provide benefits to entrepreneurs. Law Number 11 of 2020 with new rules and amendments to Article 18 and Article 19 of Law Number 41 of 1999 concerning Forestry. In Law Number 41 of 1999 concerning Forestry, it is regulated that changes in the allocation and function of forest areas are determined by the Government based on the results of integrated research. Second, the area offorest that must be maintained is at least $30 \%$ (percent) of the area of river watersheds and/or islands with a proportional distribution. However, in the Job Creation Law the minimum figure of 30\% (thirty percent) is no longer mentioned in the amendment article and the abolition of provisions related to the DPR's authority in giving approval for the transfer of functions/changes in forest areas. This paper aims to find out the principles that have been violated and the legal consequences of applying the article. The research method used in this research is the type of normative legal research. The results of this study indicate that there are deviations from the land principle and the principle of consent which can cause the norms contained in Article 18 paragraph (2) and Article 19 paragraph (2) of Law Number 11 of 2020 to be less enforceable. The abolition of the minimum area of forest area and the abolition of the DPR's authority to approve the transfer of functions/changes to forest areas, will have the potential to provide greater opportunities for deforestation.
\end{abstract}

Keywords: Principles; Norms; Forestry

DOI: $10.32801 /$ lamlaj.v6i2.256 


\section{INTRODUCTION}

Forests are complex ecosystems with diverse compositions ranging from trees, shrubs, herbs, and grasses. ${ }^{1}$ According to Law Number 41 of 1999 concerning Forestry, what is meant by forest area is a certain area designated and/or determined by the Government to maintain its existence as permanent forest. What is meant by conservation forest is a forest area with certain characteristics that have the main function of preserving plant and animal diversity and their ecosystem. Based on its status, forest consists of state forest and private forest $\mathrm{t}^{2}$, where What is meant by state forest can be in the form of customary forest. ${ }^{3}$ The government stipulates the status of customary forests as long as in reality the indigenous peoples concerned still exist and their existence is recognized. Whereas what is meant by private forest is forest located on community land/land that has been encumbered with land rights outside the state forest area. When in its development the customary law community concerned no longer exists, the customary forest management rights return to the Government (Article 5 of Law No. 41 of 1999 concerning Forestry).

Based on its function, forest consists of conservation forest, protection forest, and production forest (Article 6 of Law No. 41 of 1999 concerning Forestry). The change in the Forestry Law in Law Number 11 of 2020 con-

\footnotetext{
${ }^{1}$ Ragil Widyorini, Ikhwan Syahri, and Greitta Kusuma Dewi, "Sifat Papan Partikel Bambu Petung (Dendrocalamus Asper) Dan Bambu Wulung (Gigantochloa Atroviolacea) Dengan Perlakuan Ekstraksi," Jurnal Ilmu Kehutanan 14, no. 1 (2020): 85, https://journal.ugm.ac.id/jikfkt/article/ view/57476.

2 Salim H.S., Dasar-Dasar Hukum Kehutanan (Jakarta: Sinar Grafika, 2006) , 37.

${ }^{3}$ Ibid.
}

cerning Job Creation is believed to be able to save Indonesia because it is considered to be able to create jobs, assist small business actors, streamline regulations in terms of numbers and simplify regulations to make them more targeted. The regulation is dubbed the universal sweep law, because it is able to cut bureaucracy and provide ease of business permits as well as simple and efficient regulations to attract investors. On the other hand, the job creation law is considered to be detrimental to many groups, such as the workers such as laborers, fishermen, and farmers who are also considered to only provide benefits to entrepreneurs. For example, an unlicensed plantation in the Tesso Nilo National Park in Riau Province. The unlicensed plantation is part of the Tesso Nilo National Park ecosystem forest. There are around 474 plantation companies in Riau, but 127 of them do not have permits. These lands are used as oil palm fields, due to the high demand for palm oil processing factories ${ }^{4}$.

Law Number 11 of 2020 concerning Job Creation with new rules and amendments to articles whose purpose, however, provides opportunities for reducing or deforesting and destroying forest areas or degradation. The wise use of forests should minimize the impact of forest ecological damage. ${ }^{5}$ The substance in question is Law Number 41 of 1999 concerning Forestry Article 18 and Article 19. The essence of the two articles is that the

\footnotetext{
${ }^{4}$ Nasikh, Manajemen Ekonomi Sumberdaya Hutan Karya (Malang: Dreamitera, 2018), 27.

5 Febri Arif Cahyo Wibowo, Priyono Suryanto, and Eny Faridah, "Ekofisiologi Dan Peluang Pengembangan Durian (Durio Zibethinus) Dengan Sistem Agroforestri Di Lereng Selatan Gunung Merapi, Indonesia," Jurnal Ilmu Kehutanan 13, no. 2 (2019): 196, https://jurnal.ugm.ac.id/jikfkt/article/ view/52441.
} 
provision for a minimum area of $30 \%$ (thirty percent) forest area has been removed and changes to the allocation of forest areas are not approved by the DPR. First, in Article 18 of Law Number 41 of 1999 concerning Forestry which stipulates that the Government shall determine and maintain adequate forest area and forest cover for each watershed and or island, in order to optimize environmental benefits, social benefits, and economic benefits for local communities. . The area of forest area that must be maintained is at least $30 \%$ (percent) of the area of river watersheds and/ or islands with a proportional distribution.

However, in the Job Creation Law the minimum $30 \%$ (thirty percent) figure is no longer mentioned in the amendment article. So Article 18 Paragraph 2 only reads that the Central Government regulates the area that must be maintained according to the physical and geographical conditions of the watershed and/or island. Then add Paragraph 3 which states further provisions regarding the area of forest area that must be maintained, including in areas where there are national strategic projects regulated by Government Regulation. In Government Regulation Number 23 of 2021 concerning Forestry Implementation, Article 41 talks about the adequacy of forest area based on physical and geographical conditions on the area of watersheds, islands and/ or provinces as determined by the Minister.

Second, the abolition of provisions related to the authority of the DPR in granting approval for the transfer of functions/changes in forest areas. Previously, in Article 19 of Law Number 41 of 1999 concerning Forestry, it was regulated that changes in the allocation and function of forest areas were determined by the Government based on the results of integrated research. Changes in the allocation of forest areas that have an important impact and wide coverage and strategic value, are determined by the Government with the approval of the House of Representatives. However, in the Employment Act, the approval of the House of Representatives for changes to the designation of forest areas that have an important impact and wide scope and strategic value is no longer stated, all of which is enough with integrated research which will be further regulated by Government Regulation.

Referring to the $30 \%$ (thirty percent) figure to maintain forest areas, not all forest areas have forest cover. It creates a great opportunity to be able to exploit the forest indefinitely which will disrupt the resilience of the availability of fresh water for communities around forests and cities. Also, the absence of approval from the DPR regarding the conversion of forest land functions can make irresponsible investors commit unlawful acts arbitrarily without having to fear the laws that govern them. With the amendment of the Forestry Law in the Job Creation Act, it can have a very worrying impact, namely the opportunity for deforestation to become greater which can have a negative impact on the balance of the ecosystem.

Based on the problems above, the formulation of the problem can be drawn: What are the principles that have been violated by the provisions of Article 18 and Article 19 of the Job Creation Act? and What are the legal consequences of applying these principles? The purpose of this paper is to provide knowledge or insight to the public about the importance of the role of a principle in a norm of legislation, so as to be able to provide legal certainty properly when the contents of the norm are implemented. 


\section{ETHOD}

The research method used in this research is the of normative legal research, which is a legal research that solves problems by using statutory regulations. So that with normative research, a review of all laws and regulations related to these problems will be carried out. The research approach uses a statutory approach, namely Law Number 11 of 2020 concerning Job Creation.

Legal materials use primary legal materials and secondary legal materials. Primary legal materials consist of statutory regulations, namely the 1945 Constitution, Law Number 41 of 1999 concerning Forestry, Law Number 17 of 2014 concerning the People's Consultative Assembly (MPR), the People's Representative Council (DPR), the DPR Regional Representatives (DPD), and the Regional People's Representative Council (DPRD), and Law Number 11 of 2020 concerning Job Creation. Secondary legal materials consist of legal papers in the form of books, journals and articles. The technique of collecting legal materials used in this paper is literature study. Literature studies are carried out by reading, studying, taking notes, and reviewing legal materials related to forestry rules and concepts.

After collecting primary legal materials and secondary legal materials, an analysis was carried out using a systematic interpretation method. Systematic interpretation is interpreting statutory regulations by relating them to other laws, because the formation of a law is essentially part of the overall system of applicable legislation and it is impossible for a law to stand alone without being related to other regulations. In this paper, we use Legislation Number 11 of 2020 concerning Job Creation, where these regulations should be interrelated with Law Number 41 of 1999 concerning Forestry in order to create better legal reforms and can provide implications for solving existing forestry problems. .

\section{ANALYSIS AND DISCUSSION Differences in the application of the princi- ple of defense of area size and the principle of agreement}

Basically, a regulation, in this case a law in its creation and preparation, must be preceded by a principle. This principle is a rationale that wants to become an idea or content of a legal norm. According to P. Scholten, according to him, the principles are the tendencies that are implied by our view of morality in the law are general characteristics with all their limitations, as a general trait but which should not exist, ${ }^{6}$ while according to the Big Indonesian Dictionary, the principle is the basis, which means : something that becomes the foundation of thinking or opinion, can also be interpreted as the basis of ideals, and basic laws. The nature of the principle of law is developed by the human mind that is qualified for it. For example, the principle of justice is an important principle and includes all principles.

This principle requires that every action of a body or official always pays attention to the aspect of justice. The principle of justice demands proportional, appropriate and balanced action and is in accordance with each individual's human rights. In general, it can be concluded that the notion of legal principles is not a concrete legal regulation, but is a general basic idea or is the background of a concrete regulation. Legal principles are ba-

\footnotetext{
${ }^{6}$ Abd. Hakim G Nusantara and Nasroen Yasabari, Beberapa Pemikiran Pembangunan Hukum Di Indonesia (Bandung: Alumni, 2010), 40.
} 
sic thoughts contained in concrete law or outside concrete legal regulations. When there is a conflict between laws and regulations, the principles will appear according to their designation to determine which of the laws should be used as a reference. That is why, the principle of law is often referred to as (legal remedies legal remedies). ${ }^{7}$

Legal principles give birth to legal norms, and legal norms give birth to legal rules. What is meant by a norm is a rule that becomes a guide, a guide for someone to act or not, and behave in life in the community, such as norms of decency, legal norms, and religious norms. The basic difference between legal principles and legal norms is the principle is a general and abstract rationale, while the norm is a real rule, the principle is an idea or concept while the norm is the elaboration of the idea, the legal principle has no sanctions while the legal norm has penalty.

The main goal with the existence of law by its essence is to create an orderly social order, or to create order and balance. Every social relationship must not conflict with the provisions of existing legal regulations and apply in society. The function of law is none other than regulating the balance between human rights and obligations as social beings, and realizing justice in living together. Jeremy Bentham asserts: ${ }^{8}$

"Law is only recognized as law if it provides the greatest benefit to as many people as possible."

Thus the law should be able to provide benefits to the wider community. In a rule of law, the principle of law plays a very impor-

\footnotetext{
7 Mohammad Mahfud, Politik Hukum Di Indonesia (Jakarta: Raja Grafindo Persada, 2017), 55.

8 Sudikno Mertokusumo, Penemuan Hukum (Yogyakarta: Liberty, 2010), 41.
}

tant role. Orientation on legal principles, in other words, legal principles are the basics or directions in the formation of positive law, with regard to legal principles that must exist in the formation of practical and ideal laws. This legal principle also has several functions that can determine whether or not a basis for the formation of legal norms is good. According to Achmad Ali, this function is divided into several basic functions, and the following will be mentioned and described by the author: 9

a. Function Obey Principles (consistent) Meaning that the principle of law has a consistency that can guarantee the legal system, for example: asas in the civil law that adheres to the principle of passive for judges, which means that the judges only investigate and adjudicate the principal dispute defined by the parties litigation.

b. Function to Overcome Conflicts This principle has an important function of legal principles, for example, the principle of lex superior derogat legi inferiori is the principle which stipulates that higher-hierarchical legal regulations must take precedence over lower-level legal regulations.

c. Function of Social Engineering In terms of the function of the principle of law as social engineering, it is actually a principle of law can function as a tool engineer social

presence of the legal principle is intended to create a harmonization of all the interests of the law, and to direct legal purposes it which is basically more proportional. JJHBruggink

\footnotetext{
9 Ishaq, Dasar-Dasar Ilmu Hukum (Jakarta: Sinar Grafika, 2016), 49.
} 
explained more clearly: ${ }^{10}$

Legal principles contain a measure of value and only do not directly provide guidance, legal principles are not always positive in the rule of law, so it is difficult to be consistent, when legal principles will lose their validity, for example because the bearer of authority no longer enforces certain legal principles or justifiables no longer accept the measure of value and are no longer a reference for behavior.

Satjipto Rahardjo stated ${ }^{11}$ that the legal principle is not a concrete legal norm because the legal principle is the soul of the legal norm itself. So it can be interpreted that the principle of law is not a concrete rule of law but is the background of a concrete regulation that is general and abstract. In Article 18 Paragraph (2) and Article 19 Paragraph (2) of Law Number 41 of 1999 concerning Forestry (hereinafter referred to as the Forestry Law) and Law Number 11 of 2020 concerning Job Creation (hereinafter referred to as Law No. Job Creation) contains several principles, namely: The Defense Principle and Approval Principle.

The Defense Principle is the basis for the norms contained in Article 18 Paragraph (2) which regulates the extent of forest areas that must be maintained, while the Approval Principle forms the basis for the formation of the norms in Article 19 Paragraph (2) which regulates the involvement of the House of Representatives in providing approval of changes to the allocation of forest areas implemented by the Government. However, with the presence

\footnotetext{
${ }^{10}$ Bruggink, Refleksi Tentang Hukum PengertianPengertian Dasar Dalam Teori Hukum (Bandung: Citra Aditya Bakti, 2015), 63.

${ }^{11}$ Satjipto Rahardjo, Ilmu Hukum (Bandung: Alumni, 2010), 43.
}

of the same article in the Employment Copyright Act, which provides a slight change, this change does not provide a wise solution to existing forest problems, it can actually have a quite dangerous impact if this norm persists and is implemented. The principle of defense is violated by a change in the content of the norms contained in Article 18 Paragraph (2) of the Job Creation Law which was originally Article 18 Paragraph (2) of the Forestry Law stating:

The area of forest area that must be maintained as referred to in paragraph (1 ) a minimum of $30 \%$ (thirty percent) of the area of river watersheds and or islands with a proportional distribution.

Then it was amended by Article 18 Paragraph (2) of the Job Creation Law to:

"The Central Government regulates the area that must be maintained in accordance with the physical and geographical conditions of watersheds and/or islands."

It is clear that there are differences between the two which of course give different meanings. In this article the obligation to maintain a forest area of at least 30\% (thirty percent) is removed, replaced by the phrase paragraph (2) which reads "The Central Government regulates the area that must be maintained according to the physical and geographical conditions of the watershed and/or island". Then it was added to Article (3) which reads "further provisions regarding the area of forest that must be maintained, including in areas where there are national strategic projects, shall be regulated by a Government Regulation". The two contents of the article can give the reader an idea that the Government only thinks about strategic or profitable projects, without having to pay attention to the availability of forests that must remain to be main- 
tained for the maintenance of a good forest ecosystem.

Likewise, Article 19 paragraph (2) of the Job Creation Law has violated the Principle of Approval, which is the basis for regulating the content of norms related to the approval of the DPR in determining the allocation of forest areas. The phrase Article 19 paragraph (2) of the Forestry Law reads: "Changes to the allocation of forest areas ... are implemented by the Government with the approval of the House of Representatives", amended by Article 19 Paragraph (2) of the Job Creation Law: "Stipulations regarding the procedure for changing the designation and changing the function of forest areas... are regulated in a Government Regulation."

There is a striking difference between the two articles above, where there is a change in the content of the norm, of course there is a principle that is violated. In this article, the DPR's authority to give approval for the transfer of functions/changes to forest areas is removed. Meanwhile, Article 19 of Law Number 41 of 1999 regulates changes to the allocation of forest areas that have an important impact and wide scope and strategic value, are determined by the Government with the approval of the DPR. The absence of the DPR's approval in giving approval can make the Government take arbitrary actions in providing provisions related to the procedures for changing the designation and changing the function of forest areas.

If this continues, it is very possible that the damage to forest ecosystems is getting worse due to uncontrolled industrial activities. It is better for the Government before drafting a legal norm to think carefully about the consequences of the rules they make. Don't let a rule that was originally made to provide a solution to the problem, actually brings havoc in the future.

\section{Legal Consequences of the Application of} the Principle of Defense of Forest Areas and the Principle of Approval for the Elimination of Forest Areas

Law Number 11 of 2020 concerning Job Creation removes the provision of $30 \%$ (thirty percent) of the minimum forest area in a watershed or island. This minimum area has been regulated since 1999 in Article 18 of Law Number 41 of 1999 concerning Forestry. The principle of Defense of Area is the basis in Article 18 of the Forestry Law and the Job Creation Law, only requiring the government to maintain sufficient forest area for one area. Article 18 of Law Number 41 of 1999 reads:

(1) The government shall determine and maintain the adequacy of forest area and forest cover for each watershed and or island, in order to optimize the environmental benefits, social benefits and economic benefits of the local community.

(2) The area of forest area that must be maintained as referred to in paragraph (1) is at least $30 \%$ (thirty percent) of the area of river watersheds and or islands with a proportional distribution.

Article 18 of Law Number 11 of 2020:

(1) The Central Government determines and maintains the adequacy of forest area and forest cover for each watershed, and/or island in order to optimize the environmental benefits, social benefits, and economic benefits of the local community.

(2) The Central Government regulates the area that must be maintained according to the physical and geographical condi- 
tions of the watershed and/or island.

(3) Further provisions regarding the area of forest area that must be maintained, including in areas where there are national strategic projects, shall be regulated by a Government Regulation.

According to the Indonesian Center for Environmental Law (ICEL), an NGO revealed that the basic argument for determining the removal of a minimum area of $30 \%$ (thirty percent) forest is not strong enough, because there are several provinces in Indonesia whose forests are below 30\% (thirty percent) of the total forest area. wide area, such as in Java, but this argument is used to legalize the whole (Indonesian territory) $)^{12}$. The elimination of the minimum area creates a great opportunity to exploit the forest without limits which will disrupt the resilience of the availability of fresh water for communities around forests and cities which can lead to deforestation.

The principle of defense of forest area is needed because the determination of the figure of $30 \%$ (thirty percent) has an impact on Indonesia's social, political, economic and ecological conditions. With the abolition of the determination of the figure of $30 \%$ (thirty percent) the result is no longer in accordance with the objectives of the principle of defense of forest area. Some of the consequences of setting the figure for $30 \%$ (thirty percent) of forest area, among others: ${ }^{13}$

\footnotetext{
12 Siti Sadida Hafsyah, "Masa Depan Hutan Indonesia," Forest Digest, last modified 2020, accessed May 9, 2021, https://www.forestdigest.com/detail/785/ dampak-penghapusan-batas-hutan-30-oleh-uu-ciptakerja.

${ }^{13}$ Pungky Widiaryanto, "Rasionalitas Kebijakan Konsepsi Hutan Dan Penghapusan Batas Minimal Kawasan Hutan 30 Persen," GEMA PUBLICA :Jurnal Manajemen dan Kebijakan Publik 5, no. 2 (2020):
}

a. For provinces with forest areas with an area of less than $30 \%$ (thirty percent). If you want to change the spatial layout of the area, you have to buy land to be used as a forest area as a substitute. Especially the provinces on the island of Java, of course, it is very expensive and not possible.

b. For provinces with forest area above $30 \%$ (thirty percent).

So this provision triggers changing the forest area or trying to reduce it to $30 \%$ (thirty percent).

c. For provinces with forest area on the threshold or below 30\% (thirty percent). Tend not to resolve the problem of tenure/land tenure in forest areas either through partial release mechanisms or revision of the Provincial Spatial Plan (RTRWP), because they have to exchange forest areas.

d. Land that has qualifications as a protected area in another use area (non-forest area) and no one manages it.

On the other hand, there are forest areas whose existing conditions are no longer forested and are cultivated or utilized by the community.

The phrase Article 18 paragraph (2) of the Forestry Law "at least 30\% (thirty percent) of the area of river watersheds and or islands with a proportional distribution", can guarantee reduced deforestation because when the forest will be used by individuals or legal entities there is clarity of the area of forest that must be preserved. The amendment to the article, the purpose of removing the "minimum area for areas whose forest area is less than $30 \%$ (thirty percent)", in order to continue to

150, https://ejournal.undip.ac.id/index.php/gp/article/ view/33215/. 
carry out development, like other regions in Indonesia.

However, the ratio of forest area to land area is still $63.1 \%$ (sixty three point one percent) and the ratio of forested area to land area is about 51\% (percent) more. However, for Java, the ratio is lower than 30\% (thirty percent), while the population continues to grow. So with the elimination it has the potential to open up all forest areas for investment. There is no guarantee that these forests can be maintained, if they are in accordance with the physical and geographical conditions of the watershed and/or island.

The purpose of forestry law is to protect, utilize and conserve forests, so that they can function and provide benefits for the welfare of the people in a sustainable manner. So if "at least $30 \%$ (thirty percent) of the watershed area and/or islands are removed with a proportional distribution", it will cause deforestation and hit islands where primary forest is still dense and there is no minimum safety net to maintain the deforestation rate. again there are like Papua. This provision is also a threat to the 2018 Manokwari Declaration which stipulates West Papua's commitment to maintain $70 \%$ (seven percent) of protected areas. ${ }^{14}$ Papua will maintain 90\% (percent) of forest areas and $60 \%$ (six percent) of protected areas ${ }^{15}$.

Indonesia has contributed too much to deforestation. The provisions of Law Number 11 of 2020 put this commitment in a difficult position, because in the end the commitment

\footnotetext{
${ }^{14}$ Hafsyah, "Masa Depan Hutan Indonesia."

${ }^{15}$ Cindy Junicke Simangunsong, "UU Cipta Kerja Dan Implikasinya Kepada Hutan, Lingkungan Hidup, Dan Masyarakat Hukum Adat Di Tanah Papua," ECONUSA, accessed May 9, 2021, https://econusa.id/ pdf/6935635191020 uu cipta kerja dan implikasinya terhadap hutan, deforestasi, dan mha.pdf.
}

becomes of a very high standard compared to the commitment of the Central Government. It is better if the minimum forest area of $30 \%$ (thirty percent) is not removed, considering that the ratio of forest area in each region in Indonesia is different. It would be better if the minimum forest limit was confirmed. So that the amount of deforestation in Indonesia does not increase, but we can still protect our forests, so that the principle of defense of forest areas can be applied according to its objectives in accordance with the Forestry Law.

\section{Changes in the Approval of Forest Area Designations}

Law Number 41 of 1999 has the authority to change the designation and function of forest areas in the hands of the Central Government, but it is still distinguished between changes that have an important impact, wide scope, and strategic nature and changes that do not have a significant impact. spacious and strategic. The principle of approval is the basis of Article 19 of Law Number 41 of 1999. Amendment to Article 19 of Law Number 11 of 2020 eliminates the use of the principle of approval which reads:

(1) Changes in the designation and changes in the function of forest areas are determined by the Central Government taking into account the results integrated research.

(2) Provisions regarding the procedure for changing the allocation and changing the function of forest areas as referred to in paragraph (1) shall be regulated in a Government Regulation.

The abolition of the DPR's authority in granting approval for the transfer of functions/ changes to forest areas previously regulated 
in Article 19 of Law Number 41 of $1999^{16}$ had an important impact and had a broad scope and strategic value. After the amendment to Article 19 of Law Number 11 of 2020, the approval of the House of Representatives for changes to the designation of forest areas that have an important impact and broad coverage and strategic value is no longer stated, all of which is enough with an integrated research which will be further regulated by Government Regulation.

After eliminating the distinction and stricter procedures, the process of changing the allocation and function of forest areas became much simpler and faster. Because there is no need for the approval of the DPR, and it is enough to consider the results of integrated research. ${ }^{17}$ But of course, with the new provisions in Law Number 11 of 2020, there is a threat that increasing deforestation is increasingly open, especially for non-forestry activities and activities that have an important and wide-ranging impact which no longer gets more security due to the loss of DPR participation in make decisions with the government.

The Job Creation Act has been controversial since its inception, in which the drafting was too hasty, with a large number of articles and covering almost all regulations, it was impossible to create synergy, especially with a very short and hasty system. Many articles in the Job Creation Law are problematic or

\footnotetext{
${ }^{16}$ Zenwen Pador, "UU Cipta Kerja Melegalkan Deforestasi Dan Degradasi Hutan," Mongabay : Situs Berita Lingkungan, last modified 2020, accessed May 11, 2021, https://www.mongabay.co.id/2020/10/07/ uu-cipta-kerja-melegalkan-deforestasi-dandegradasi-hutan/.

${ }^{17}$ Simangunsong, "UU Cipta Kerja Dan Implikasinya Kepada Hutan, Lingkungan Hidup, Dan Masyarakat Hukum Adat Di Tanah Papua.”
}

contrary to legal principles, so that the contents of the norms are not properly conveyed in their aims and objectives. One of them is in the forestry sector, where the articles are problematic or contradict the Forestry Law itself, one of which is Article 19 paragraph (2). The DPR has the authority to draft a statutory regulation, which in Article 20 Paragraph (2) of the 1945 Constitution states:

"Every draft law is discussed by the House of Representatives and the President for mutual approval."

Then it is continued with Article 22 Paragraph (2) of the 1945 Constitution which states:

"The government regulation must obtain the approval of the House of Representatives in the next trial."

The 1945 Constitution has regulated such provisions, but the legislators are still deviated, in addition to the 1945 Constitution, the authority of the House of Representatives in giving approval is also regulated in Article 71 letter b of Law Number 17 of 2014 concerning the Consultative Assembly. The People's Representative Council (MPR), the People's Representative Council (DPR), the Regional Representatives Council (DPD), and the Regional People's Representative Council (DPRD) stated:

Giving approval or not giving approval to government regulations in lieu of laws proposed by the President to become law law.

It is increasingly apparent that the Job Creation Law still has many shortcomings, there are still many articles that deviate from the original provisions. Either deliberately changed because of certain interests or indeed the legislators unintentionally. If by accident it seems impossible, because in formulating a draft law it cannot be done arbitrarily, it must 
have gone through a long meeting process where in this forum the Government and the DPR can formulate the best or even minimal errors. If the contents of Article 19 Paragraph (2) are still carried out, which is making laws and regulations without the approval of the House of Representatives, then based on Article 22 Paragraph (3) of the 1945 Constitution, if it does not get approval, then the government regulation must be revoked.

These rules can be revoked and no longer enforced, the government should be firm in carrying out the rules it has made, including really not enforcing legal rules that deviate from existing provisions in order to create legal order and legal harmony in society. So that the public can feel the legal justice that should be where this is the ultimate goal of the creation of a statutory regulation.

\section{CONCLUSION}

With the differences in the use of the principle of area and the principle of defense, this can cause the norms contained in Article 18 paragraph (2) and Article 19 paragraph (2) of Law Number 11 of 2020 to be less able to carry out the contents of the norm. Because the aims and objectives have been different from the previous provisions. This can lead to new problems in the future.

The principle of defense of forest area is needed because the determination of the figure of $30 \%$ (thirty percent) has an impact on Indonesia's social, political, economic and ecological conditions. The loss of DPR participation in making joint decisions with the government makes the principle of approval no longer visible in the Job Creation Act.

\section{Suggestion}

government should be more careful in drafting a statutory regulation, especially in the use of legal principles in a legal norm. Do not let just one thing or another that is contrary to the principle can have a detrimental impact on society in the future.

Changes by eliminating the minimum area of forest area and the authority of the DPR will only increase deforestation. It is recommended that Article 18 and Article 19 of the Forestry Law do not need to be amended. It is hoped that the Government can explicitly and concretely regulate the boundaries and efforts to protect forests, the environment, and MHA in each implementing regulation.

\section{BIBLIOGRAPHY}

\section{Books}

Bruggink. Refleksi Tentang Hukum Pengertian-Pengertian Dasar Dalam Teori Hukum. Bandung: Citra Aditya Bakti, 2015.

H.S., Salim. Dasar-Dasar Hukum Kehutanan. Jakarta: Sinar Grafika, 2006.

Ishaq. Dasar-Dasar Ilmu Hukum. Jakarta: Sinar Grafika, 2016.

Mahfud, Mohammad. Politik Hukum Di Indonesia. Jakarta: Raja Grafindo Persada, 2017.

Mertokusumo, Sudikno. Penemuan Hukum. Yogyakarta: Liberty, 2010.

Nasikh. Manajemen Ekonomi Sumberdaya Hutan Karya. Malang: Dreamitera, 2018.

Nusantara, Abd. Hakim G, and Nasroen Yasabari. Beberapa Pemikiran Pembangunan Hukum Di Indonesia. Bandung: Alumni, 2010.

Rahardjo, Satjipto. Ilmu Hukum. Bandung: Alumni, 2010.

\section{Journal}

Hafsyah, Siti Sadida. "Masa Depan Hutan Indonesia." Forest Digest. Last modified 2020. Accessed May 9, 2021. https://www. 
forestdigest.com/detail/785/dampakpenghapusan-batas-hutan-30-oleh-uucipta-kerja.

Wibowo, Febri Arif Cahyo, Priyono Suryanto, and Eny Faridah. "Ekofisiologi Dan Peluang Pengembangan Durian (Durio Zibethinus) Dengan Sistem Agroforestri Di Lereng Selatan Gunung Merapi, Indonesia." Jurnal Ilmu Kehutanan 13, no. 2 (2019): 196. https://jurnal.ugm.ac.id/ jikfkt/article/view/52441.

Widiaryanto, Pungky. "Rasionalitas Kebijakan Konsepsi Hutan Dan Penghapusan Batas Minimal Kawasan Hutan 30 Persen.” GEMA PUBLICA :Jurnal Manajemen dan Kebijakan Publik 5, no. 2 (2020): 150. https://ejournal.undip.ac.id/index.php/gp/ article/view/33215/.

Widyorini, Ragil, Ikhwan Syahri, and Greitta Kusuma Dewi. "Sifat Papan Partikel Bambu Petung (Dendrocalamus Asper) Dan Bambu Wulung (Gigantochloa Atroviolacea) Dengan Perlakuan Ekstraksi." Jurnal Ilmu Kehutanan 14, no. 1 (2020): 85. https://journal.ugm.ac.id/ jikfkt/article/view/57476.

\section{Internet}

Pador, Zenwen. "UU Cipta Kerja Melegalkan Deforestasi Dan Degradasi Hutan." Mongabay : Situs Berita Lingkungan. Last modified 2020. Accessed May 11, 2021. https://www.mongabay.co.id/2020/10/07/ uu-cipta-kerja-melegalkan-deforestasidan-degradasi-hutan/.

Simangunsong, Cindy Junicke. "UU Cipta Kerja Dan Implikasinya Kepada Hutan, Lingkungan Hidup, Dan Masyarakat Hukum Adat Di Tanah Papua." ECONUSA. Accessed May 9, 2021. https://econusa. id/pdf/6935635191020 uu cipta kerja dan implikasinya terhadap hutan, deforestasi, dan mha.pdf.

\section{Law and Regulation}

Government Regulation No. 23 of 2021 on Forestry Administration.

Law of the Republic of Indonesia No. 11 of 2020 on Job Creation.

Law No.41 of 1999 on Forestry

Law No. 17 of 2014 regarding People's Consultative Assembly

The 1945 Constitution of the Republic of Indonesia 